University of Wollongong

Research Online

Faculty of Business - Papers (Archive)

Faculty of Business and Law

$1-1-2014$

\title{
The effect of noncognitive traits on health behaviours in adolescence
}

Silvia Mendolia

University of Wollongong, smendoli@uow.edu.au

Ian Walker

Lancaster University

Follow this and additional works at: https://ro.uow.edu.au/buspapers

Part of the Business Commons

Research Online is the open access institutional repository for the University of Wollongong. For further information contact the UOW Library: research-pubs@uow.edu.au 


\title{
The effect of noncognitive traits on health behaviours in adolescence
}

\begin{abstract}
This paper investigates the relationship between personality traits and health behaviours in adolescence using a large and recent cohort study. In particular, we investigate the impact of locus of control, selfesteem and work ethics at ages 15-16 years on the incidence of health behaviours such as alcohol consumption, cannabis and other drug use, unprotected and early sexual activity and sports and physical activity. We use matching methods to control for a very rich set of adolescent and family characteristics, and we find that personality traits do affect health behaviours. In particular, individuals with external locus of control, low self-esteem or with low levels of work ethics seem more likely in engage in risky health behaviours.
\end{abstract}

Keywords

health, traits, noncognitive, behaviours, effect, adolescence

Disciplines

Business

Publication Details

Mendolia, S. \& Walker, I. (2014). The effect of noncognitive traits on health behaviours in adolescence. Health Economics, 23 (9), 1146-1158. 


\section{The Effect of Non-Cognitive Traits on Health Behaviours in Adolescence}

by

Silvia Mendolia†, and lan Walkerł

${ }^{\dagger}$ University of Wollongong, School of Economics

${ }^{\ddagger}$ Lancaster University, Department of Economics silvia_mendolia@uow.edu.au

ian.walker@lancaster.ac.uk

Corresponding author:

Dr. Silvia Mendolia

School of Economics

Faculty of Business

Building 40, Room 215

University of Wollongong NSW 2522

Other author:

Professor Ian Walker

The Management School

Lancaster University

Bailrigg

Lancaster

LA1 4YX 
JEL codes: J13, 121

\begin{abstract}
:
This paper investigates the relationship between personality traits in adolescence and health behaviours using a large and recent cohort study. In particular, we investigate the impact of locus of control, self-esteem and work ethics at age 15-16, on the incidence of health behaviours such as: alcohol consumption, cannabis and other drug use, unprotected and early sexual activity, and sports and physical activity. We use matching methods to control for a very rich set of adolescent and family characteristics and we find that personality traits do affect health behaviours. In particular, individuals with external locus of control, low self-esteem, or with low levels of work ethics seem more likely in engage in risky health behaviours.
\end{abstract}




\section{Introduction}

The objective of this paper is to analyse the role of non-cognitive traits on health behaviours in adolescence. In particular, we study the effect of locus of control, self-esteem and work ethics recorded when the child is 15-16 on subsequent risky health behaviours up to when she/he is 19-20 years old.

We contribute to the existing literature in two ways. First, we provide evidence from a more recent dataset based on a large cohort of English children born in 1990 and followed for seven years, starting in 2004. Our analysis is focused on personality traits in adolescence. A variety of studies have shown that personality traits are relatively malleable, at least over the early life cycle. There is some evidence that policy interventions can target adolescents to promote useful traits and suppress harmful ones early in life. Existing studies either rely on relatively dated data (NLSY79 for Heckman et al., 2006 and BCS70 for Preevo and ter Weel, 2013) or do not have a specific focus on adolescents (Chiteji, 2010 and Cobb-Clark et al., 2012). Secondly, we use propensity score matching (PSM) to investigate the relationship between personality and health as well as OLS estimation. OLS is widely regarded as providing an estimate of an upper bound on the causal effect and PSM may be thought to tighten that bound.

Risky behaviour with respect to health is important and costly. In particular, risky health behaviours among youths are a major concern for many Western developed countries (see US Centre for Disease Control and Prevention, 2011). Many studies point to early initiation of these behaviours being strongly related to dependency in adulthood (Chen and Kandell, 1995).

The issue seems to be particularly relevant for the British population: according to the UNICEF Innocenti Report on child poverty (UNICEF, 2007) the prevalence of risky behaviours amongst UK youths is higher than in other similar OECD countries. Hale and 
Viner (2012) show that British children aged between 16 and 24 years are likely to drink over double the daily recommended amounts on their heaviest drinking day in the last week, and their frequent drug use is much higher than for older respondents (Craig and Hirani, 2010 and NHS, 2011). Abortion and Sexually Transmitted Infections (STIs) rates peak in adolescence (Department of Health, 2011) and 16-24-year olds account for over half of new STIs diagnosed in the UK (Health Protection Agency, 2011).

The incidence of risky health behaviour in the UK is higher than in other OECD countries and the impact on a public universal health care system, such as the NHS, is likely to be considerable. So providing further evidence of the effect on personality on health behaviours from a recent cohort of English teenagers could be an important contribution to the current policy debate.

Individual risky health behaviours pose a major burden for health, and for the health services. In 2006-07, smoking-related costs on the NHS were $£ 3.3$ billion, alcohol costs $£ 3.3$ billion, overweight and obesity costs $£ 5.1$ billion (Scarborough et al., 2011). In England and Wales in 2003/04, drug use was estimated to impose economic and social costs of $£ 15.4$ billion (Gordon et al., 2006). In the United States in 2000, the annual health costs for STIs reached US\$17 billion (Centre for Disease Control and Prevention, 2000). There are also other social and economic costs related to risky health behaviours, such as increased incidence of violence and crime, accidents, mental health disorders and loss of educational opportunities.

The rest of this paper is organized as follows. Section 2 provides a brief overview of the existing literature; Section 3 presents the data and explains the personality indicators and health-related outcomes that it contains; Section 4 and 5 discuss the estimation methods and the results; and Section 6 concludes with a discussion of the policy implications of the work. 
The headline finding of the research is that we broadly support the idea that non-cognitive skills are important in determining health choices in early adult life: individuals with external locus of control, low self-esteem, and low levels of work ethics ${ }^{1}$ are all more likely to engage in risky behaviours, such as cannabis and drugs taking, and unprotected sex.

\section{Overview of the existing literature}

The evidence on the effect of personality on health has suggested a variety of transmission mechanisms, such as health-related behaviours, longevity, and social relationships. Almlund et al. (2011) provide an excellent review of the studies conducted in this area. They conclude that most of the literature from psychology and health sciences shows that personality traits such as conscientiousness, openness to experience, and agreeableness generally have a positive effect on longevity and health behaviours (Hampson et al., 2007; Gale et al., 2008; Hampson et al., 2010; Lodi-Smith et al., 2010). However, most of these studies tend to use small or unrepresentative samples (see Roberts et al., 2007 for a review, and Bogg and Roberts, 2004 for a meta-analysis).

The economics literature in this area is limited. Heckman, et al. (2006) use data from the US NLSY1979 and show that locus of control and self-esteem affect the probability of smoking, using marijuana, and being a teenager mother. Chiteji (2010) uses data from the US Panel Study of Income Dynamics (PSID) to show that locus of control and self-efficacy (which refers to the evaluation of one's ability to be effective performing tasks that are necessary to realize an outcome) are associated with lower alcohol consumption and more physical exercise. Preevo and ter Weel (2013) use data from the BCS 1970 and show that early conscientiousness decreases adult BMI, alcoholism, cannabis use and smoking. Lastly, Cobb-Clark et al. (2012) use Australian data to show that individuals with an internal locus of control are more likely to eat well and exercise regularly.

\footnotetext{
${ }^{1}$ These concepts are explained and defined in Section 3.
} 
Economics literature has also investigated the stability of personality traits over the lifecycle (Cobb-Clark and Schurer, 2013) and the relationship between personality traits and economic preferences (see for example Becker et al., 2012); education outcomes, such as study behaviour (Delaneji et al., 2012), class attendance (Lounsbury, Steel, Loveland et al. 2004), human capital investments (Coleman and Deleire 2003); and labour market outcomes, such as occupational attainment, wages (Duncan and Duniform, 1998; Osborne Groves, 2005; Nyhuns and Pons, 2005; Cobb-Clark and Tan, 2011; Drago, 2011) and unemployment transitions (Cuesta and Budria, 2012).

Conventional economic analysis relies heavily on using economic incentives to affect behaviour. While there is some evidence that suggests that this can be successful in preventing the adoption of unhealthy behaviours there is clearly room for working on behaviour through preferences as well. Cobb-Clark et al. (2012) suggests that economic constraints can provide only a limited explanation of the choices relating to health behaviours in standard economic models based on utility maximisation. Personality traits can have profound effects on both preferences and constraints, and economists have only recently become interested in investigating the role of non-cognitive traits in investments in health. Indeed, health economists have devoted a significant amount of effort to investigating the determinants of risky health behaviours and have shown the importance of factors such as: education (Grossman, 2000 and 2006; Cutler and Lleras-Muney, 2005), risk attitudes (Anderson and Mellor, 2008), time preference (Van Der Pol, 2011), and peer effects and social networks (Van Der Pol, 2011). However, this literature has not taken personality traits directly into account. Thus, it is natural to extend this exploration of the role of preferences to consider also the role of psychological traits using large-scale and nationally representative data with a stronger focus on the causal relationships between personality and health. 


\section{Data}

This paper uses data from the Longitudinal Study of Young People in England (LSYPE). This is a large scale cohort survey of English adolescents, selected to be representative of the young people in England but at the same time as oversampling specific groups. Adolescents were interviewed for the first time when they were in school year 9 in 2004 at the age of 14. In addition, LSYPE can be linked to the National Pupil Database (NPD), a pupil-level administrative database that matches pupil and school characteristics data to pupil attainment and contains detailed information on test scores for all the LSYPE children. We use this data to get information about LSYPE children's results in test scores at age 11 (Key Stage 2 scores).

In the first wave around 15,500 young people were interviewed. In the first four waves, parents/guardians were also interviewed. Our final sample includes around 5,000 observations of children with non-missing information on personality traits, cognitive ability, health behaviours and other essential information on the child's birth and family background (the selected observations were not significantly different from the original data in terms of their observable characteristics).

The study is managed by the Department of Education and covers a wide range of topics, including academic achievements, family relationships, attitudes toward school, family and labour market, and some more sensitive or challenging issues, such as risky health behaviours (smoking, alcohol drinking, drug taking), personal relationships, etc. We focus on four groups of outcomes observed at wave 6: cannabis and drug use; sex behaviour; drinking, and sport and physical activity. These questions are answered by the child through self-completion questionnaires, in order to minimise the risk of misreporting on these sensitive topics. Unfortunately, information about smoking is only available in LSYPE until 
wave 3 and no information is collected about nutrition habits. Table 1 lists the variables that constitute the behavioural outcomes of interest.

Table 1 here

Personality is complex and factor analysis has been utilised extensively in personality psychology to identify a number of common factors derived from a variety of questions (Cobb-Clark et al., 2012; Piatek and Pinger 2010; and Almlund et al., 2011). While our data does not include information about the Big Five personality traits that have been the focus of some recent research (see Almlund et al., 2011 for a review of possible alternatives), it does include a series of questions on locus of control, self-esteem and attitudes to work.

Locus of control refers to individual beliefs about whether life events are mostly internally or externally determined (Rotter, 1966). People with an external locus of control believe that what happens in life is largely determined by events beyond their control, while individuals with internal locus of control generally believe that life events are mostly caused by their own decisions and behaviours. We measure locus of control using children's responses to six questions (see the Appendix for details). We follow previous literature in the field (see for example Cobb-Clark et al., 2012 and Piatek and Pinger 2010) and use factor analysis to create indexes of internal and external locus of control. Children are coded as external if they have a score in the top quartile of the distribution of the external index, derived from factor analysis. We also test this definition, by classifying children as external if they have a score in the top third or fifth of the distribution of the external index (see Appendix table A1).

Self-esteem refers to an individual perception of her/his own value. LSYPE data includes two questions on self-esteem (see Appendix for details) asked at waves 2 and 4 . We construct an indicator of low self-esteem equal to 1 if they have placed themselves in the 
most distressed category for one of the two questions at least once between the two waves (around $26 \%$ of the children in the sample) ${ }^{2}$.

Almlund et al. (2011) suggest that competence, dutifulness, self-discipline, perseverance and work-ethic are all facets of Conscientiousness. LSYPE includes four questions on working attitudes (see the Appendix for details) and we use factor analysis to create an index of work ethics. Children are coded as having high work ethics, if they have a score in the top quartile of the distribution of the index.

We estimate two versions of our model, progressively increasing the set of independent variables. All of the variables we control for are, arguably, pre-determined variables - that is, not themselves influenced by personality traits. Our first, most parsimonious, model only includes at-birth characteristics such as: birth-weight; whether the child was premature; ethnic background; sex of the child; and family characteristics such as marital status and age of the mother at birth. In the second preferred model we include a measure of cognitive ability at age 11 (Key Stage 2 scores), and other family's characteristics (measured at wave 1) which are unlikely to have changed since the child's birth, such as: maternal education, child and mother disability, grandparents’ education, and older siblings. ${ }^{3}$ We include a measure of cognitive ability in our preferred specification as this is likely to have an important effect on health behaviours and because we want to test whether personality traits capture independent effects other than the cognitive ability. Further, Key Stage 2 score is unlikely to be endogenous with respect to personality, as it is derived through a standardized and objective test (rather than through teachers' or parents' evaluations) and it is completed at age 11, 4 years earlier that the measure of personality utilised in our analysis.

\footnotetext{
${ }^{2}$ Alternative/more restrictive indicators of low self-esteem were constructed to test the robustness of our estimates and results are available on request.

${ }^{3}$ Extensions to Model 2 were estimated that also controlled for maternal employment and household income at wave 1. Results are reported in Table A5 in the Appendix.
} 
We provide a correlation matrix of personality traits and cognitive ability in Appendix Table A2.

Table 2 presents descriptive statistics on the outcome variables, broken down by personality traits. Individuals with external locus of control and low self-esteem are more likely to engage in risky behaviours, such as cannabis and drug-taking, or early and unprotected sexual activity and less likely to engage in regular physical activity. Interestingly, the association with alcohol consumption is less pronounced. On the other hand, children with a high level of work ethics seem less likely to engage in risky health behaviours.

Table 2 here.

\section{Estimation}

While we begin by using Ordinary Least Squares, to control for observable confounders, this is well known to lead to biased estimates of the causal effects because of neglected heterogeneity. The linear model can be written as:

$$
H_{i}=\alpha+P_{i}^{\prime} \beta+X_{i}^{\prime} \gamma+\varepsilon_{i}
$$

where $H_{i}$ represents a particular health behaviour, $P_{\mathrm{i}}$ ' is a vector of psychological traits (binary indicators of external locus of control; low self-esteem; high work ethics) and $X_{\mathrm{i}}$ ' is a vector of child's and family's characteristics. We cannot, in this data, address the selection on unobservables problem. There is simply no quasi-experimental variation across our sample to exploit. However, we can go some way towards addressing the other problems. However, we do try to lower the upper bound provided by OLS estimation, through the inclusion of a more detailed set of independent variables. Second, we exploit propensity score matching that does not rely on functional form assumptions and restricts inference to samples where we can find overlap in the distribution of covariates across the treatment. PSM may be thought of as assuming the selection problem way because it relies on conditional independence that implies no selection on the unobservables conditional on the observables. 
On the other hand, matching methods have some desirable features: the observations used to estimate the causal effect are selected without reference to the outcome, as in a controlled experiment; it dominates other methods based on selection on observables (like OLS), thanks to its more convincing comparison of treated and control units; it offer interesting insights for a better understanding of the estimation of causal effects; and there is some (debated) evidence suggesting that it contributes to a reduction in the selection bias (see Dehejia and Wahba 2002, Dehejia 2005, and Smith and Todd 2004). At the very least, matching provides a convincing way to select the observations on which other estimation methods can be based. Matching is more robust than OLS because it does not restrict the way in which personality may affect behaviours to be linear, and inference is limited to samples that are effectively comparable, based on the covariates distribution. Matching attaches appropriate weights to the observations in the control group, so that the distribution of their observable characteristics is realigned to the treatment group.

Propensity Score Matching has been used in various recent papers investigating the determinants of child well-being (see for example Ruhm, 2008; Berger et al., 2005; and Goodman and Sianesi, 2005) and the effect of personality traits (Caliendo et al., 2010). The idea of propensity score matching is to match children with different personality traits (for example, with and without low self-esteem) who are as comparable as possible in all other respects so that they have similar propensities to be treated. More specifically, firstly we estimate the conditional probability of having a specific personality trait, called the propensity score, like having low self-esteem for each child, given our covariates. Then, estimated propensity scores are used to create a matched control group and for each treated child we find the comparison member with the closest propensity score. Non-matched individuals are dropped from the analysis. Our analysis is performed using psmatch2 and appropriate tests have been run, in order to compare covariate distributions across our 
matched groups to ensure that adequate balance has been obtained (results available in Appendix Table A3) ${ }^{4}$.

\section{Results}

The results from the estimation of the effect of personality traits on health behaviours are presented in Tables 3 and 4. The effect of personality traits on health behaviours is very stable and the size and magnitude of the effects do not change when we include one or more traits at the same time. The results presented in both Tables 3 and 4 suggest that noncognitive skills generally have significant effects on health behaviours and the effects are sizeable. In our discussion, we will focus on the results from PSM estimation of Model 2 (see Table 4), as this is our preferred specification ${ }^{5}$.

Figures 1 and 2 show the distribution of propensity scores across treatment and control groups. Both graphs show that there is sufficient overlap between the treatment and control groups.

Figure 1 here

Figure 2 here

Table 3 here

Table 4 here

Personality has a notable effect on some risky health behaviours, and particularly cannabis and drug use, unprotected sex and low level of physical activity. The results from

\footnotetext{
${ }^{4}$ Our approach is similar to Goodman and Sianesi (2005) and we use propensity score matching with the nearest neighbour method with replacement (as it has been shown to reduce bias relative to matching without replacement, see Dehejia and Wahba, 2002) and then used the common option, so that off-support observations are automatically dropped. Similar results were obtained with other matching methods.

${ }^{5}$ Estimates are provided for Model 2 and not for more complex models because it seems unwise to match according to data that are more likely to have changed between wave 1 and wave 6 . However, sensitivity analyses have been run including some further variables (e.g. household income and maternal employment at wave 1). Main results are unchanged and are available in the Appendix.
} 
PSM estimation are generally consistent with those reported from OLS estimation, with slightly lower effects, on average, reported from PSM estimation. Nonetheless the degree to which PSM tightens the OLS bound is surprisingly small. OLS seems to do a reasonable job despite our reservations. In most cases, where the OLS estimates are statistically significant the corresponding PSM estimate is typically insignificantly different and generally slightly smaller. Results from balance test for PSM model are reported and discussed in Appendix Table A3.

In Model 2, having external locus of control increases the risk of taking cannabis, having ever had unprotected sexual intercourse, or being younger than 16 at first sexual intercourse by about $15-16 \%$ with respect to the sample mean and has a stronger negative effect on the chances of trying other drugs (+ 40\%). These negative effects of external locus of control are not surprising, as external individuals tend to think that their choices have less impact on their future, which they believe are mostly driven by luck and external circumstances. As a consequence, they also seem less cautious in engaging in various risky health behaviours. As already noted, personality traits do not seem to have a relevant effect on drinking habits.

Young people with low self-esteem face an increased risk of taking drugs (+50\%) and cannabis $(+30 \%)$, engaging in early or unprotected sexual activity (around $+18 \%$ ), and having a low level of physical activity (+20\%). A high level of work ethics seems to decrease chances of engaging in risk-taking behaviours, such as cannabis or drug use (-25\% to $-30 \%$ ), early or unprotected sex (results between $-13 \%$ and $-16 \%$ ) and low levels of physical activity (-30\%.).

As expected, children with low self-esteem seem to underestimate the consequences of their risky health behaviours and, possibly because they struggle to see themselves as 
valuable, they are less cautious with respect to their health. On the other hand children with strong work ethics are more likely to carefully evaluate the consequences of their actions and to have a proactive orientation towards the future.

Our findings are consistent with previous literature from psychology and economics. For example, Hampson et al. (2007) show that extraversion, agreeableness and conscientiousness affect health-related behaviours, such as smoking, diet and exercise (with correlation coefficients between 0.06 and 0.12); Gale, Batty and Deary (2008) find that a one standard deviation increase in age-10 locus of control decreases the risk of adult obesity by 8\%; Cobb-Clark et al. (2012), show that one standard deviation increase in internal behaviour increases the chances of healthy habits by around 2 p.p.

As shown in Appendix Table A4, the effects of personality traits are comparable with the effect of other important variables, such as: the presence of siblings, the child's gender, having a young or single mother, or growing up with a disabled parent, and are, in most cases stronger than the effect of child's special needs and maternal education.

Generally, children who were less healthy at birth or had a disability or a special need are less likely to engage in risky behaviours. Boys seem more likely to experiment with cannabis, drugs, excessive drinking and risky sexual behaviour, and so are children who grew up in a single-parent family or have older siblings. Interestingly, ethnic minorities (and especially children with an Asian background) seem less likely to engage in risky behaviours and maternal education increases the chances of taking drugs or cannabis or being a heavy drinker (possibly because of higher income and less supervision). Children who perform better in test scores at age 11 also have slightly increased chances of trying cannabis, drugs or being heavy drinkers, but the size of the effect is marginal. 
Additional sensitivity tests are included in the Appendix. As already explained, Appendix Table A1 presents results from the estimation with OLS and PSM of a model where we test our definition of external locus of control. Individuals are defined as being external if they have a score in the top third or fifth of the distribution of the index of locus of control. The results from Table A1 are consistent with previous ones. External locus of control increases the chances of engaging in risky behaviours such as trying cannabis or other drugs, and engaging in early or unprotected sexual activity. Appendix Table A5 shows results from the estimation of a model which also includes maternal employment status and family income at wave 1. Main results are unchanged and the effect of personality traits on health behaviours does not seem to be affected by the inclusion of these additional variables.

\section{Discussion and policy implications}

In this section, we will focus on the interpretation of our results and, in particular, on the possible policy implications of our analysis. Our results show that personality plays a role in determining teenager choices in terms of risky health behaviours. Therefore, there is a potential for policies to exploit possible changes in personality in order to promote positive health choices later in life.

According to Borghans et al., (2008) "the answer to the question of whether change in personality is possible must be a definitive yes [...]. However, change may be more difficult later in the life cycle”. Cobb-Clark and Schurer (2013) have shown that changes in locus of control are modest on average, and are concentrated among the young or very old, so personality traits seem to be more likely to be malleable earlier in life. Furthermore, the psychological literature has shown that genetic factors are largely responsible for stability in personality in adulthood whereas environmental factors are mostly responsible for change (Blonigen, et al., 2006; Plomin and Nesselroade, 1990). Therefore, it is essential to 
understand if and how it is possible to act on those environmental factors that mediate changes in personality.

Public policies focused on improving outcomes for children and adolescents have traditionally been centered on educational outcomes, such as increasing the number of years of schooling, or improving school attainments, as education is a strong predictor of labour market participation, future wages, and occupational choices. However, the role of noncognitive skills in promoting positive economic and social behaviours and human capital investments has recently received increased attention from economists and policy makers. Public policies focused on teenager and young people are gradually moving away from simply improving education outcomes or access to higher education for individual from low socio-economic status, to fostering a variety of non-cognitive skills and emotional literacy that are correlated with life-time outcomes.

A variety of interventions have been suggested that exploit the early malleability of personality to improve long term outcomes. Selective personality-targeted interventions that focus on specific personality traits as risk factors for alcohol and substance use have recently been shown to be more effective than universal prevention programs aiming at increase general knowledge about the harms of alcohol and substance misuse (see for example Conrod et al., 2010; Foxcroft and Tsertsvadze, 2011; Conrod et al., 2013). The PreVenture Program was implemented for children between 13-15 years old in Canada and UK since 2001 and included tailored interventions based on screening results for four personality dimensions that have been linked to increased risk for alcohol and drug use. Subsequent evaluations showed that students in the intervention groups showed significantly lower use of alcohol and drugs than their peers in the control groups (Conrod et al., 2006; Conrod et al., 2010; O’LearyBarret et al., 2010). 
Almlund et al. (2011) discuss the importance of parental investments, education and interventions to promote positive changes in personality. Their work show the effectiveness of interventions targeting younger children and specifically focusing on improving selfcontrol and positive behaviour (Bierman et al., 2010), building up self-esteem and selfefficacy (Social and Character Consortium, 2010), as well as interventions targeting adults and focusing on Openess to experience (Jackson et al., 2010). The well-known Perry Preschool program, consisting of pre-school sessions and home visits did improve important later-life outcomes through personality and is thought to have worked primarily through socio-economic channels.

In the UK, an example of these policies is SEAL (Social and Emotional Aspects of Learning), a voluntary program designed to develop the social and emotional skills of all school pupils in the areas of self-awareness, managing feelings, empathy, motivation and social skills. SEAL is currently being implemented in around $90 \%$ of primary schools and $70 \%$ of secondary schools. Various evaluations of SEAL have been conducted. Hallam, Rhamie and Shaw (2006) concluded that primary SEAL "had a major impact on children's well-being, confidence, social and communication skills, relationships, including bullying, playtime behaviour, pro-social behaviour and attitudes towards schools”.

In the USA, the program "Second Step” focuses on core social-emotional skills such as empathy and communication, emotion management, and problem solving and has been implemented for students from Kindergarten to Middle School. Evaluations of Middle School Second Step have shown positive effect of the program on social competence, pro-social skills and behaviours, and decrease in depression and anxious behaviours (Taub, 2002).

The evaluations of a number of existing policies have shown that changing personality is possible and interventions are useful, especially when they target young 
children and adolescents. We believe that our study shows some of the ultimate benefits of these programs, which span a wide range of health-behaviours, which might have important long lasting consequences on individuals’ lives and society as a whole. 


\section{References}

Almlund M., Duckworth A., Heckman J.J., Kautz T. 2011. Personality Psychology and Economics. In Handbook of the Economics of Education. Vol. 4, , ed. Hanushek E.A., Machin S. Wobmann L., 1-181. Amsterdam: Elsevier.

Anderson L.R. Mellor J.M. 2008. Predicting Health Behaviors with an Experimental Measure of Risk Preference. Journal of Health Economics 27: 1260-1274.

Becker A., Deckers T., Dohmen T., Kosse F., Falk A. 2012. The Relationship Between Economic Preferences and Psychological Personality Measures. Annual Review of Economics 4: 453-478.

Berger L.M., Hill J., Waldfogel J. 2005. Maternity Leave, Early Maternal Employment and Child Health and Development in the US. Economic Journal 115: 29-47.

Bierman, K. L., Coie, J. D., Dodge, K. A., Greenberg, M. T., Lochman, J. E., McMahon, R. J. Pinderhughes, E (2010). The Effects of a Multiyear Universal Social-Emotional Learning Program: The Role of Student and School Characteristics. Journal of Consulting and Clinical Psychology 78: 156-168.

Blonigen D. M., Hicks B. M., Krueger, R. F., Patrick C. J., Iacono W.G. 2006. Continuity and Change in Psychopathic Traits as Measured Via Normal-Range Personality: A Longitudinal-Biometric Study. Journal of Abnormal Psychology 15: 85-95.

Bogg T.B, Roberts W. 2004. Conscientiousness and Health-related Behaviors: A Metaanalysis of the Leading Behavioral Contributors to Mortality. Psychological Bulletin 130: 887-919.

Borghans Duckworth A., Heckman J., Ter Weel B. 2008. The Economics and Psychology of Personality Traits, NBER Working Paper Series 13810.

Caliendo M., Cobb-Clark D., Uhlendorff A. 2010. Locus of Control and Job Search Strategies. IZA Discussion Paper n. 4750.

CDC [Centers for Disease Control and Prevention], Division of STD Prevention. 2000. Sexually Transmitted Disease Surveillance 1999. Atlanta: Department of Health and Human Services, Centers for Disease Control and Prevention (CDC)

CDC [Centers for Disease Control and Prevention]. 2011. Youth Risk Behaviors Surveillance. United States, 2011. Atlanta: Department of Health and Human Services, Centers for Disease Control and Prevention (CDC)

Chen K., Kandel D.B. 1995. The Natural History of Drug Use from Adolescence to the MidThirties in a General Population Sample. American Journal of Public Health 85:4147.

Chiteji N. 2010. Time Preferences, Non-cognitive Skills and Well-being across the Life Course: Do Non-cognitive Skills Encourage Healthy Behavior? American Economic Revie. 100: 200-204.

Cobb-Clark D., Tan M. (2011). Noncognitive Skills, Occupational Attainment, and Relative Wages. Labour Economics 18, 1-13.

Cobb-Clark D., Kassenboehmer S.C., Schurer S. 2012. Healthy Habits: The Connection between Diet, Exercise, and Locus of Control. IZA Discussion Paper No. 6789. 
Cobb-Clark D., Schurer S. 2013. Two Economists' Musings on the Stability of Locus of Control. The Economic Journal 123: 358-400.

Coleman, M., DeLeire, T. 2003. An Economic Model of Locus of Control and the Human Capital Investment Decision. The Journal of Human Resources 38: 701-721.

Conrod, P. J., Stewart, S. H., Comeau, N., \& Maclean, A. M. 2006. Efficacy of CognitiveBehavioral Interventions Targeting Personality Risk Factors for Youth Alcohol Misuse. Journal of Clinical Child and Adolescent Psychology 35: 550-563.

Conrod, P. J., Castellanos-Ryan, N., \& Strang, J. 2010. Brief, Personality-Targeted Coping Skills Interventions and Survival as a Non-Drug User over a 2-Year Period During Adolescence. Archives of General Psychiatry 67: 85-93.

Conrod P.J., O’Leavy Barret M.A., Newton N., Topper L., Castellanos-Ryan N., Mackie C., Girard A. 2013. Effective of a Seective, Personality -Targeted Prevention Program for Adolescent Alcohol Use and Misuse. Journal of American Medical Association Psychiatry 70: 334-342.

Craig R, Hirani V., (eds). 2010. Health Survey for England—2009: Health and Lifestyles. London: National Centre for Social Research.

Cuesta M., Budria S., (2012), Unemployment Persistence: How Important are NonCognitive Skills?, IZA Discussion Paper 6654

Cutler D., Lleras Muney A. 2005. Understanding Differences in Health Behaviors by Education. Journal of Health Economics 29: 1-28.

Dehejia, R.H. \& Wahba, S. 2002. Propensity Score-Matching Methods for Non-Experimental Causal Studies. The Review of Economics and Statistics 84: 151-61.

Dehejia, R.H. 2005. Practical Propensity Score Matching: a Reply to Smith and Todd. Journal of Econometrics 125: 355-364.

Delaney, L., Harmon, C., Ryan, M. 2012. The Role of Noncognitive Traits in Undergraduate Study Behaviours. Economics of Education Review 32: 181-195.

Department of Health. 2011. Abortion Statistics, England and Wales: 2010. London: Department of Health.

Drago, F. (2011), Self-Esteem and Earnings. Journal of Economic Psychology 32, 480-488.

Duncan G.J., Dunifon R.(1998), Soft-Skills and Long-Run Labor Market Success. Research in Labor Economics. S. W. Polachek, ed. Stamford, CT, JAI Press. 17, 123-149.

Foxcroft D.R., Tsertsvadze A. 2011. Universal School-based Prevention Programs for Alcohol Misuse in Young People. Cochrane Database of Systematic Reviews 5, doi.

Gale C.R., Batty G. D., Deary I.J. 2008. Locus of Control at Age 10 Years and Health Outcomes and Behaviors at Age 30 Years: The 1970 British Cohort Study. Psychosomatic Medicine 70: 397-403.

Goodman A., Sianesi B. 2005. Early Education and Children's Outcomes: How Long Do the Impacts Last? Fiscal Studies 26: 513-548.

Gordon L, Tinsley L, Godfrey C et al. (2006). The Economic and Social Costs of Class A Drug Use in England and Wales, 2003/04. In: Measuring Different Aspects of Problem Drug Use: Methodological Developments. Singleton N, Murray R, Tinsley L (eds.) Home Office online report 16/06. London: Home Office. 
Grossman M. 2000. The Human Capital Model. In Handbook of Health Economics, Culyer AJ, Newhouse JP (eds).North-Holland: Amsterdam.

Grossman M. 2006. Education and Nonmarket outcomes. In Handbook of the Economics of Education, Hanushek E, Welch F (eds). North-Holland: Amsterdam.

Jackson J. J., Hill P. L., Payne B. R., Roberts B. W. , Stine-Morrow E. A. L. 2010. Can an Old Dog Learn (and Want to Experience) New Tricks? Cognitive Training Increases Openness in Older Adults. Unpublished Manuscript. University of Illinois, Department of Psychology.

Hale D.R., Viner 2012. Policy Responses to Multiple Risk Behaviours in Adolescents. Journal of Public Health 34:11-19.

Hallam, S., Rhamie, J., Shaw, J. 2006. Evaluation of the Primary Behaviour and Attendance Pilot. Research Report RR717. Nottingham: DfES Publications.

Hampson S.E., Goldberg L.R., Vogt T.M., Dubanoski J.P. 2007. Mechanisms by Which Childhood Personality Traits Influence Adult Health Status: Educational Attainment and Healthy Behaviors. Health Psychology 26: 121-125.

Hampson S.E., Tildesley E., Andrews J.A., Luyckx K.and Mroczek D.K. 2010. The Relation of Change in Hostility and Sociability During Childhood to Substance Use in Mid Adolescence. Journal of Research in Personality 44, 103-114.

Health Protection Agency. 2011. STI Annual Data Tables. http://www.hpa.org.uk/stiannualdatatables

Heckman J.J., Stixrud, J., Urzua, S. 2006. The Effects of Cognitive and Noncognitive Abilities on Labor Market Outcomes and Social Behavior. Journal of Labor Economics 24: 411-482.

Lodi-Smith J., Jackson J., Bogg T., Walton K., Wood D., Harms P., Roberts B. 2010. Mechanisms of health: Education and health-related behaviours partially mediate the relationship between conscientiousness and self-reported physical health. Psychology and Health 25: 305-319.

Lounsbury J.W., Steel R.P., Loveland J.M. and Gibson L.W. (2004), An Investigation of Personality Traits in Relation to Adolescent School Absenteeism. Journal of Youth and Adolescence 33, 457-466.

NHS Information Centre. 2011. Statistics on Drug Misuse: England, 2010. London: NHS Information Centre.

Nyhus E.K., Pons E. (2005), The Effects of Personality on Earnings. Journal of Economic Psychology, 26, 363-384.

O'Leary-Barrett, M., Mackie, C. J., Castellanos-Ryan, N., Al-Khudhairy, N., \& Conrod, P. J. 2010. Personality-Targeted Interventions Delay Uptake of Drinking and Decrease Risk of Alcohol-Related Problems when Delivered by Teachers. Journal of the American Academy of Child and Adolescent Psychiatry. 49: 954-963.

Osborne Groves M. 2005. How Important is your Personality? Labor market returns to personality for women in the US and UK. Journal of Economic Psychology 26: 827841.

Piatek R., Pinger P. 2010. Maintaining (Locus of) Control? Assessing the Impact of Locus of Control on Education Decisions and Wages. IZA Discussion Paper 5289. 
Plomin R., Nesselroade J. 1990. Behavioral Genetics and Personality Change. Journal of Personality 58: 191-220.

Preevo T., ter Weel B. 2013. The Importance of Early Conscientiousness for Socio-Economic Outcomes. Paper presented at SOLE meeting 2013.

Roberts, B.W., Kuncel, N.R., Shiner, R., Caspi, A., Goldberg L.R. 2007. The Power of Personality: The Comparative Validity of Personality Traits, Socioeconomic Status, and Cognitive Ability for Predicting Important Life Outcomes. Perspectives on Psychological Science 2: 313-345.

Rotter, J. 1966. Generalized Expectancies for Internal Versus External Control of Reinforcement, Psychological Monographs, 80.

Ruhm C.J. 2008. Maternal Employment and Adolescent Development. Labour Economics 15: 958-983.

Scarborough P., Bhatnagar P., Wickramasinghe K.K., Allender S., Foster C., Rayner M. 2011. The Economic Burden of Ill Health due to Diet, Physical Inactivity, Smoking, Alcohol and Obesity in the UK: an Update to 2006-07 NHS costs. Journal of Public Health 33:527-535.

Smith J., Todd P., 2004. Does Matching Overcome Lalonde’s Critique of Nonexperimental Estimators. Journal of Econometrics 125: 305-353.

Social and Character Development Research Consortium. 2010. Efficacy of Schoolwide Programs to Promote Social and Character Development and Reduce Problem Behavior in Elementary School Children (Ncer 2011-2001). National Center for Education Research, Institute of Education Sciences, U.S. Department of Education.

Taub, J. 2002. Evaluation of the Second Step Violence Prevention Program at a Rural Elementary School. School Psychology Review, 31: 186-200

Unicef Innocenti Research Centre 2007. An Overview of Child Well-Being in Rich Countries in Unicef, Child Poverty in Perspective: An Overview of Child Well-Being in Rich Countries, Innocenti Report Card 7, 2007 UNICEF Innocenti Research Centre, Florence.

Van Der Pol, M. 2011. Health, Education and Time Preferences. Health Economics 20: 917929. 


\section{Tables}

Table $1 \quad$ Outcomes

Health Behaviours Variable

Ever tried cannabis $\quad=1$ if yes

Ever tried other drugs such as: cocaine, $\quad=1$ if yes

LSD, ecstasy, heroin, crack, speed

Age of first sexual intercourse

$=1$ if 15 or younger

Ever had unprotected sex

$=1$ if yes and ever had unprotected sex

Heavy drinking

$=1$ if drinking at least 3-4 times a week in the last year

Often drunk

$=1$ if gets drunk most or every times drinks

Never drunk

$=1$ if never gets drunk when has an alcoholic drink

Low physical activity

$=1$ if does sports hardly ever or never. 
Table 2 - Descriptive statistics of outcome variables by locus of control, self-esteem and work ethics

\begin{tabular}{lcccc} 
& $\begin{array}{c}\text { Whole } \\
\text { sample }\end{array}$ & External & $\begin{array}{c}\text { Low Self- } \\
\text { Esteem }\end{array}$ & High Work ethics \\
\hline Mean (sd) & & & & \\
\hline Ever tried cannabis & $0.33(0.47)$ & $0.37(0.48)$ & $0.40(0.49)$ & $0.23(0.42)$ \\
Ever tried other drugs & $0.12(0.32)$ & $0.15(0.35)$ & $0.16(0.36)$ & $0.07(0.25)$ \\
Had first sexual intercourse $<16$ & $0.31(0.46)$ & $0.38(0.48)$ & $0.36(0.48)$ & $0.25(0.43)$ \\
Ever had unprotected sex & $0.43(0.49)$ & $0.50(0.50)$ & $0.49(0.50)$ & $0.36(0.48)$ \\
Heavy drinking & $0.23(0.42)$ & $0.21(0.41)$ & $0.22(0.42)$ & $0.20(0.39)$ \\
Often drunk & $0.29(0.46)$ & $0.33(0.47)$ & $0.33(0.47)$ & $0.28(0.45)$ \\
Never drunk & $0.09(0.28)$ & $0.09(0.29)$ & $0.08(0.28)$ & $0.11(0.31)$ \\
Low physical activity & $0.13(0.33)$ & $0.15(0.35)$ & $0.17(0.37)$ & $0.12(0.32)$ \\
\hline
\end{tabular}

Note: All outcomes are recorded at wave 6. 
Table 3 Effect of personality traits on health behaviours - OLS Estimation Results

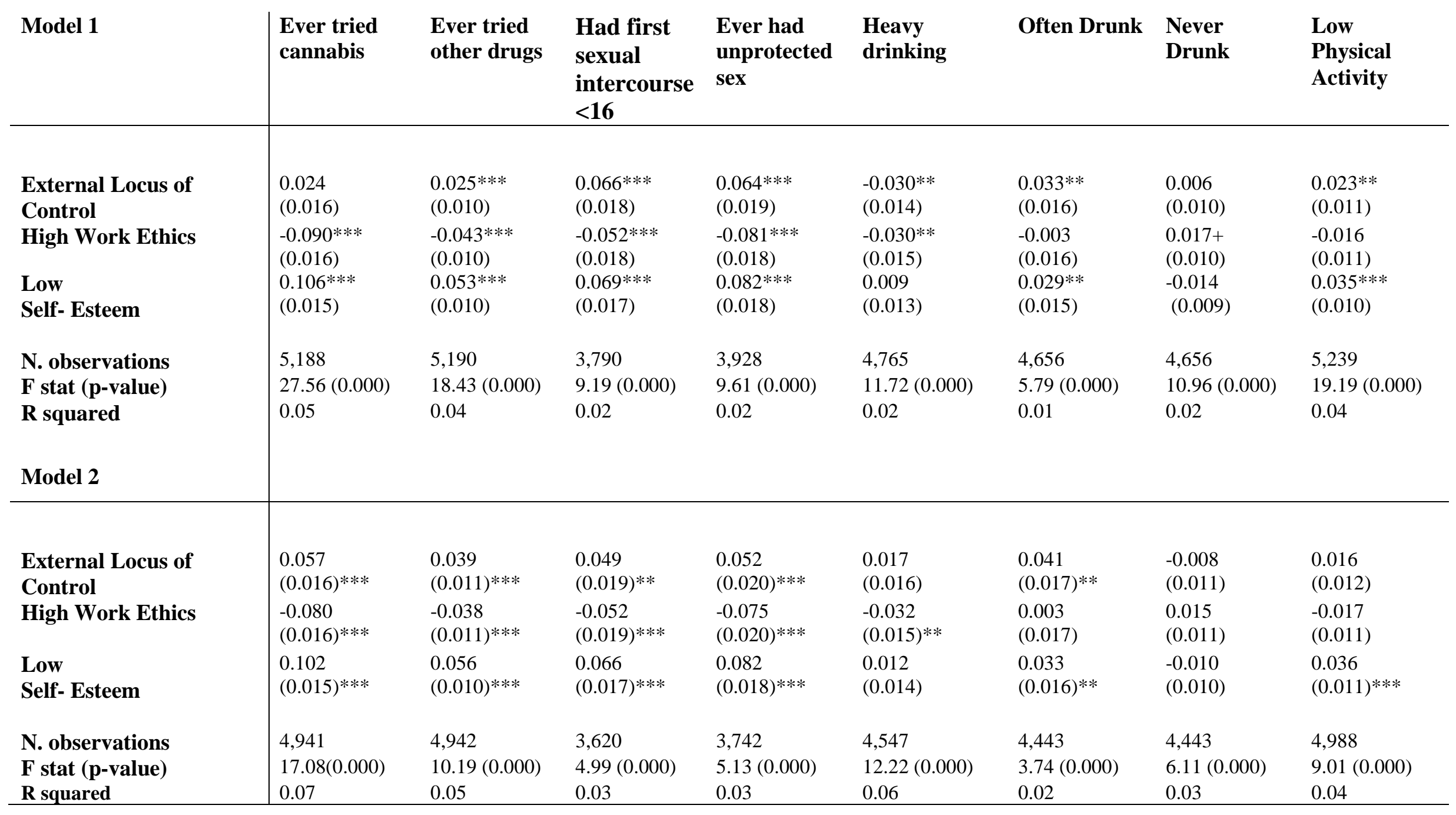

Note: Standard errors are in brackets. * indicates that the underlying coefficient is significant at $10 \%$ level, ** at $5 \%$ and $* * *$ at $1 \%$. Additional variables included in the analysis are listed at p. 9 . 
Table 4 Effect of personality traits on health behaviours - Propensity Score Matching Results

\begin{tabular}{|c|c|c|c|c|c|c|c|c|}
\hline Model 1 & $\begin{array}{l}\text { Ever tried } \\
\text { cannabis }\end{array}$ & $\begin{array}{l}\text { Ever tried } \\
\text { other drugs }\end{array}$ & $\begin{array}{l}\text { Had first } \\
\text { sexual } \\
\text { intercourse } \\
<16\end{array}$ & $\begin{array}{l}\text { Ever had } \\
\text { unprotected sex }\end{array}$ & $\begin{array}{l}\text { Heavy } \\
\text { drinking }\end{array}$ & $\begin{array}{l}\text { Often } \\
\text { Drunk }\end{array}$ & Never Drunk & $\begin{array}{l}\text { Low } \\
\text { Physical } \\
\text { Activity }\end{array}$ \\
\hline $\begin{array}{l}\text { External Locus of } \\
\text { Control }\end{array}$ & $\begin{array}{l}0.062 \\
(0.031)^{* *}\end{array}$ & $\begin{array}{l}-0.001 \\
(0.022)\end{array}$ & $\begin{array}{l}-0.013 \\
(0.035)\end{array}$ & $\begin{array}{l}0.068 \\
(0.036)+\end{array}$ & $\begin{array}{l}0.005 \\
(0.03)\end{array}$ & $\begin{array}{l}0.058 \\
(0.032)^{*}\end{array}$ & $\begin{array}{l}0.020 \\
(0.021)\end{array}$ & $\begin{array}{l}0.042 \\
(0.021)^{* *}\end{array}$ \\
\hline N. observations & 5,419 & 5,420 & 3,960 & 4,113 & 4,984 & 4,871 & 4,871 & 5,474 \\
\hline $\begin{array}{l}\text { High Work } \\
\text { Ethics }\end{array}$ & $\begin{array}{l}-0.039 \\
(0.028)\end{array}$ & $\begin{array}{l}-0.059 \\
(0.018)^{* * *}\end{array}$ & $\begin{array}{l}-0.090 \\
(0.033)^{* * *}\end{array}$ & $\begin{array}{l}-0.071 \\
(0.035)^{* * *}\end{array}$ & $\begin{array}{l}-0.005 \\
(0.027)\end{array}$ & $\begin{array}{l}0.008 \\
(0.031)\end{array}$ & $\begin{array}{l}0.011 \\
(0.022)\end{array}$ & $\begin{array}{l}-0.044 \\
(0.022)^{*}\end{array}$ \\
\hline N. observations & 6,819 & 6,827 & 4,865 & 5,064 & 6,216 & 6,072 & 6,072 & 6,893 \\
\hline $\begin{array}{l}\text { Low } \\
\text { Self- Esteem }\end{array}$ & $\begin{array}{l}0.117 \\
(0.030)^{* * *}\end{array}$ & $\begin{array}{l}0.049 \\
(0.019)^{* * *}\end{array}$ & $\begin{array}{l}0.0499 \\
(0.033)\end{array}$ & $\begin{array}{l}0.121 \\
(0.034)^{* * *}\end{array}$ & $\begin{array}{l}0.034 \\
(0.027)\end{array}$ & $\begin{array}{l}0.026 \\
(0.031)\end{array}$ & $\begin{array}{l}-0.003 \\
(0.021)\end{array}$ & $\begin{array}{l}0.017 \\
(0.023)\end{array}$ \\
\hline N. observations & 7,621 & 7,629 & 5,417 & 5,650 & 6,942 & 6,776 & 6,776 & 7,721 \\
\hline \multicolumn{9}{|l|}{ Model 2} \\
\hline $\begin{array}{l}\text { External Locus of } \\
\text { Control }\end{array}$ & $\begin{array}{l}0.056 \\
(0.024)^{* * *}\end{array}$ & $\begin{array}{l}0.052 \\
(0.0159)^{* * *}\end{array}$ & $\begin{array}{l}0.045 \\
(0.027)^{*}\end{array}$ & $\begin{array}{l}0.067 \\
(0.028)^{* * *}\end{array}$ & $\begin{array}{l}0.006 \\
(0.021)\end{array}$ & $\begin{array}{l}0.039 \\
(0.024)\end{array}$ & $\begin{array}{l}-0.001 \\
(0.016)\end{array}$ & $\begin{array}{l}0.016 \\
(0.017)\end{array}$ \\
\hline $\begin{array}{l}\text { High Work } \\
\text { Ethics }\end{array}$ & $\begin{array}{l}-0.075 \\
(0.022)^{* * *}\end{array}$ & $\begin{array}{l}-0.036 \\
(0.014)^{* * *}\end{array}$ & $\begin{array}{l}-0.049 \\
(0.026)^{*}\end{array}$ & $\begin{array}{l}-0.050 \\
(0.027)^{*}\end{array}$ & $\begin{array}{l}-0.029 \\
(0.021)\end{array}$ & $\begin{array}{l}0.005 \\
(0.023)\end{array}$ & $\begin{array}{l}0.022 \\
(0.015)\end{array}$ & $\begin{array}{l}-0.039 \\
(0.016)^{* * *}\end{array}$ \\
\hline $\begin{array}{l}\text { Low } \\
\text { Self- Esteem }\end{array}$ & $\begin{array}{l}0.097 \\
(0.021)^{* * *}\end{array}$ & $\begin{array}{l}0.062 \\
(0.014)^{* * *}\end{array}$ & $\begin{array}{l}0.061 \\
(0.024)^{* * *}\end{array}$ & $\begin{array}{l}0.069 \\
(0.025)^{* * *}\end{array}$ & $\begin{array}{l}0.021 \\
(0.019)\end{array}$ & $\begin{array}{l}0.035 \\
(0.022)\end{array}$ & $\begin{array}{l}0.005 \\
(0.013)\end{array}$ & $\begin{array}{l}0.032 \\
(0.016)^{* * *}\end{array}$ \\
\hline N. observations & 4,941 & 4,942 & 3,620 & 3,742 & 4,547 & 4,443 & 4,443 & 4,988 \\
\hline
\end{tabular}

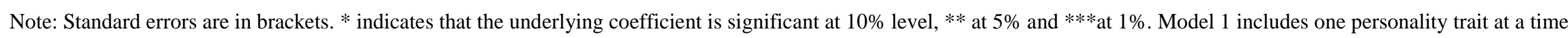
and other basic covariates listed at p. 9. Model 2 includes all personality traits at one time and other covariates as discussed at p. 9. 
Figure 1 - Histogram of propensity scores of treatment vs. control group (Model 2 High work ethics = 1 -Outcome: Ever tried drugs)

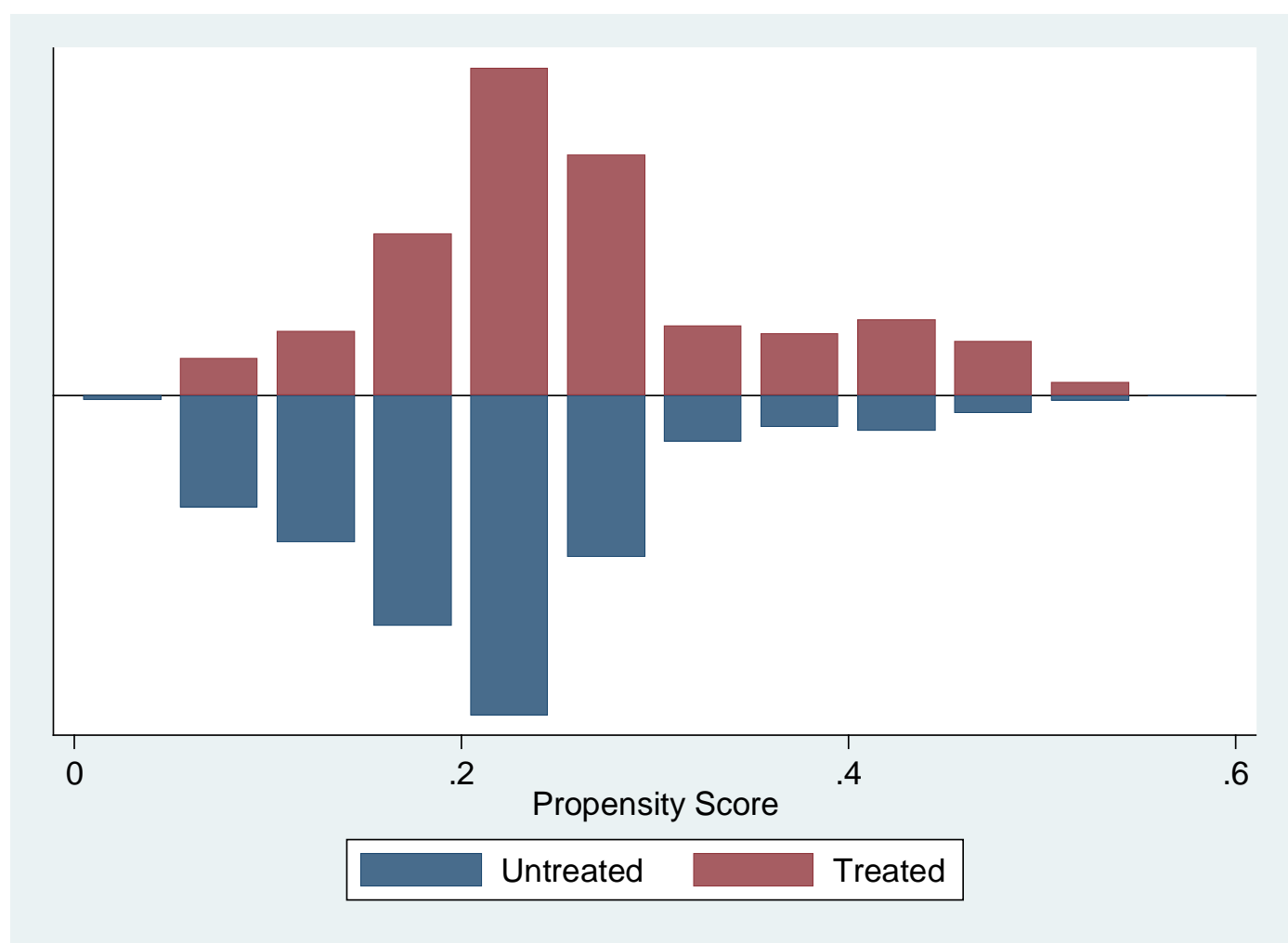

Figure 2 - Kernel graphs of propensity score for treated and control group

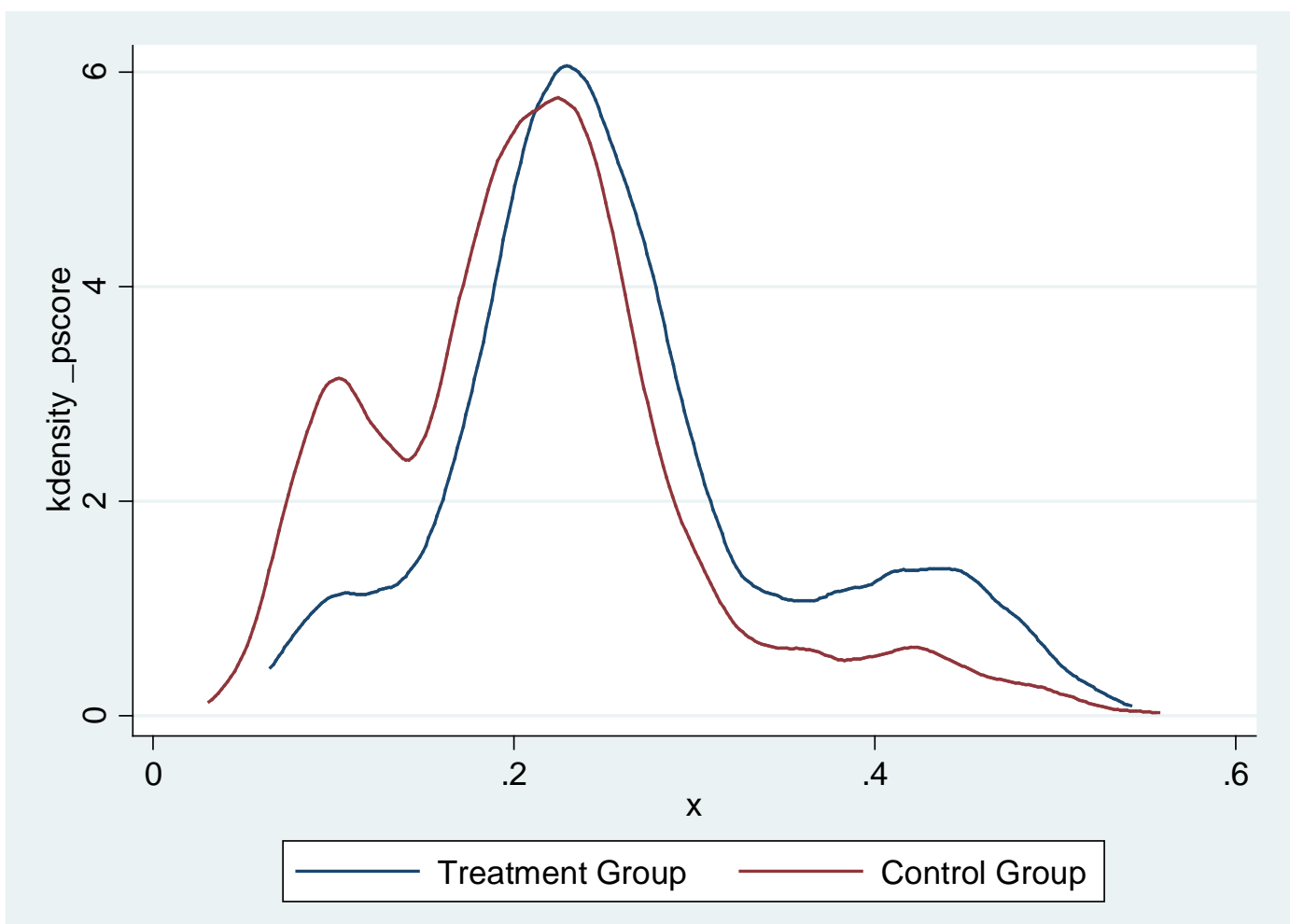




\section{Appendix}

\section{Locus of control - Questions in LSYPE}

1. I can pretty much decide what happens in my life

2. If someone is not a success in life, it is usually his fault

3. How well you get in this world is mostly a matter of luck

4. Even if I do well at school, I will have a hard time

5. People like me do not have much of a chance

6. If you work hard at something, you will usually succeed

Possible answers:

- Strongly agree

- Agree

- Disagree

- Strongly disagree

\section{Work ethics - Questions in LSYPE}

1. Doing well at school means a lot to me

2. At school, I work as hard as I can

3. Working hard at school now will help me to get on later in life

4. If you work hard at something, you will usually succeed

Possible answers:

- Strongly agree

- Agree

- Disagree

- Strongly disagree

\section{Self-esteem - Questions in LSYPE}

1. How useful you have felt recently?

2. How much you have been thinking of yourself as a worthless person recently?

Possible answers:

- Not at all

- No more than usual

- Rather more than usual

- Much more than usual. 
Table A1 Estimation Results from Model 2 - Different definitions of external locus of control

\begin{tabular}{|c|c|c|c|c|c|c|c|c|}
\hline $\begin{array}{l}\text { Model } 2-\text { Different } \\
\text { Indicators of External } \\
\text { Locus of Control }\end{array}$ & $\begin{array}{l}\text { Ever tried } \\
\text { cannabis }\end{array}$ & $\begin{array}{l}\text { Ever tried } \\
\text { other drugs }\end{array}$ & $\begin{array}{l}\text { Had first } \\
\text { sexual } \\
\text { intercourse } \\
<16\end{array}$ & $\begin{array}{l}\text { Ever had } \\
\text { unprotected sex }\end{array}$ & $\begin{array}{l}\text { Heavy } \\
\text { drinking }\end{array}$ & $\begin{array}{l}\text { Often } \\
\text { Drunk }\end{array}$ & Never Drunk & $\begin{array}{l}\text { Low } \\
\text { Physical } \\
\text { Activity }\end{array}$ \\
\hline \multicolumn{9}{|l|}{ OLS } \\
\hline $\begin{array}{l}\text { External Locus of } \\
\text { Control - Top third of } \\
\text { the distribution }\end{array}$ & $\begin{array}{l}0.035 \\
(0.015)^{* *}\end{array}$ & $\begin{array}{l}0.027 \\
(0.010)^{* * *}\end{array}$ & $\begin{array}{l}0.023 \\
(0.018)\end{array}$ & $\begin{array}{l}0.039 \\
(0.019) * *\end{array}$ & $\begin{array}{l}0.016 \\
(0.014)\end{array}$ & $\begin{array}{l}0.025 \\
(0.016)\end{array}$ & $\begin{array}{l}-0.009 \\
(0.010)\end{array}$ & $\begin{array}{l}0.021 \\
(0.011)^{* *}\end{array}$ \\
\hline $\begin{array}{l}\text { External Locus of } \\
\text { Control - Top fifth of } \\
\text { the distribution }\end{array}$ & $\begin{array}{l}0.041 \\
(0.018) * *\end{array}$ & $\begin{array}{l}0.037 \\
(0.013)^{* * *}\end{array}$ & $\begin{array}{l}0.044 \\
(0.021)^{* *}\end{array}$ & $\begin{array}{l}0.042 \\
(0.022)^{*}\end{array}$ & $\begin{array}{l}0.006 \\
(0.017)\end{array}$ & $\begin{array}{l}0.021 \\
(0.019)\end{array}$ & $\begin{array}{l}-0.005 \\
(0.012)\end{array}$ & $\begin{array}{l}0.024 \\
(0.013)^{*}\end{array}$ \\
\hline \multicolumn{9}{|l|}{ PSM } \\
\hline $\begin{array}{l}\text { External Locus of } \\
\text { Control - Top third of } \\
\text { the distribution }\end{array}$ & $\begin{array}{l}0.021 \\
(0.021)\end{array}$ & $\begin{array}{l}0.031 \\
(0.014)^{* *}\end{array}$ & $\begin{array}{l}0.035 \\
(0.025)\end{array}$ & $\begin{array}{l}0.029 \\
(0.026)\end{array}$ & $\begin{array}{l}-0.002 \\
(0.020)\end{array}$ & $\begin{array}{l}0.0223 \\
(0.022)\end{array}$ & $\begin{array}{l}-0.007 \\
(0.014)\end{array}$ & $\begin{array}{l}0.0348 \\
(0.015) * *\end{array}$ \\
\hline $\begin{array}{l}\text { External Locus of } \\
\text { Control - Top fifth of } \\
\text { the distribution }\end{array}$ & $\begin{array}{l}0.0411 \\
(0.020)^{*}\end{array}$ & $\begin{array}{l}0.036 \\
(0.019)^{*}\end{array}$ & $\begin{array}{l}0.0096 \\
(0.031)\end{array}$ & $\begin{array}{l}0.062 \\
(0.031)+\end{array}$ & $\begin{array}{l}0.018 \\
(0.022)\end{array}$ & $\begin{array}{l}0.0230 \\
(0.027)\end{array}$ & $\begin{array}{l}-0.005 \\
(0.018)\end{array}$ & $\begin{array}{l}0.008 \\
(0.020)\end{array}$ \\
\hline N. observations & 4,941 & 4,942 & 3,620 & 3,742 & 4,547 & 4,443 & 4,443 & 4,988 \\
\hline
\end{tabular}

Note: Standard errors are in brackets. * indicates that the underlying coefficient is significant at $10 \%$ level, ** at $5 \%$ and ***at $1 \%$. Additional variables included in the analysis are listed at p. 9. 
Table A2 Correlation Matrix between Key Stage 2 Score and personality traits

\begin{tabular}{l|llll} 
& Key Stage 2 & $\begin{array}{l}\text { External Locus } \\
\text { of Control }\end{array}$ & Low Self-Esteem & $\begin{array}{l}\text { High Work } \\
\text { Ethics }\end{array}$ \\
\hline $\begin{array}{l}\text { Key Stage 2 } \\
\text { External Locus of }\end{array}$ & 1.000 & -0.2856 & 1.000 & \\
Control & & & & \\
Low Self-Esteem & -0.0283 & 0.1299 & 1.000 & \\
High Work Ethics & 0.0150 & -0.1111 & -0.0537 & 1.000
\end{tabular}


Table A3 Balance tests for Propensity Score Matching (Estimation of the effect of high work ethics on use of drugs - Model 2)

\begin{tabular}{|c|c|c|c|c|c|c|}
\hline Variable & $\begin{array}{l}\text { Mean - } \\
\text { Treated }\end{array}$ & $\begin{array}{c}\text { Mean } \\
\text { Control }\end{array}$ & \% Bias & $\begin{array}{c}\text { \% } \\
\text { Reduct. } \\
\text { in Bias } \\
\end{array}$ & $\mathbf{t}$ & $\mathbf{p}$ \\
\hline KS2 Score & 28.281 & 27.997 & 8.0 & -12.0 & 1.89 & 0.06 \\
\hline $\begin{array}{l}\text { External } \\
\text { behaviour }\end{array}$ & 0.127 & 0.133 & -1.4 & 95.7 & -0.38 & 0.705 \\
\hline $\begin{array}{l}\text { Low self- } \\
\text { esteem }\end{array}$ & 0.231 & 0.252 & -4.8 & 58.3 & -1.14 & 0.254 \\
\hline Birth-weight & 3.261 & 3.237 & 4.0 & 74.1 & 0.94 & 0.346 \\
\hline Premature birth & 0.109 & 0.113 & -1.5 & 60.3 & -0.34 & 0.736 \\
\hline $\begin{array}{l}\text { Main parent has } \\
\text { disability }\end{array}$ & 0.193 & 0.191 & 0.5 & 74.5 & 0.11 & 0.914 \\
\hline $\begin{array}{l}\text { Grandparents } \\
\text { university }\end{array}$ & 0.099 & 0.100 & -0.3 & 92.2 & -0.07 & 0.944 \\
\hline $\begin{array}{l}\text { Child has a } \\
\text { disability }\end{array}$ & 0.131 & 0.139 & -2.4 & -910.7 & -0.56 & 0.576 \\
\hline $\begin{array}{l}\text { N. older } \\
\text { siblings }\end{array}$ & 0.777 & 0.757 & 1.9 & 83.6 & 0.48 & 0.628 \\
\hline $\begin{array}{l}\text { Child has } \\
\text { special needs }\end{array}$ & 0.152 & 0.172 & -5.2 & 59.7 & -1.27 & 0.204 \\
\hline $\begin{array}{l}\text { Mother HE sub } \\
\text { degree }\end{array}$ & 0.143 & 0.131 & 3.4 & -651.5 & 0.80 & 0.422 \\
\hline $\begin{array}{l}\text { Mother } \\
\text { A level }\end{array}$ & 0.125 & 0.112 & 3.6 & 59.3 & 0.92 & 0.357 \\
\hline $\begin{array}{l}\text { Mother } \\
\text { GCSE A-C }\end{array}$ & 0.139 & 0.156 & -4.8 & 9.6 & -1.14 & 0.255 \\
\hline $\begin{array}{l}\text { Mother } \\
\text { GCSE <C }\end{array}$ & 0.309 & 0.287 & 4.7 & -50.9 & 1.12 & 0.265 \\
\hline $\begin{array}{l}\text { Mother } \\
\text { Other qual }\end{array}$ & 0.080 & 0.085 & -2.0 & -27.5 & -0.46 & 0.644 \\
\hline $\begin{array}{l}\text { Mother } \\
\text { No qual }\end{array}$ & 0.0271 & 0.038 & -7.1 & -403.8 & -1.55 & 0.122 \\
\hline Sex - Male & 0.468 & 0.464 & 0.7 & 92.6 & 0.17 & 0.865 \\
\hline $\begin{array}{l}\text { Single parent at } \\
\text { birth }\end{array}$ & 0.185 & 0.188 & -0.9 & 1.0 & -0.22 & 0.827 \\
\hline $\begin{array}{l}\text { Mother }<20 \text { at } \\
\text { birth }\end{array}$ & 0.051 & 0.061 & -4.5 & -1315.0 & -1.01 & 0.311 \\
\hline $\begin{array}{l}\text { Ethnic } \\
\text { background: } \\
\text { Black }\end{array}$ & 0.074 & 0.084 & -4.8 & 71.0 & -0.94 & 0.346 \\
\hline $\begin{array}{l}\text { Ethnic } \\
\text { background: } \\
\text { Asian }\end{array}$ & 0.169 & 0.160 & 2.7 & 89.4 & 0.57 & 0.567 \\
\hline $\begin{array}{l}\text { Ethnic } \\
\text { background: } \\
\text { Mixed }\end{array}$ & 0.066 & 0.0623 & 1.5 & 65.5 & 0.35 & 0.729 \\
\hline
\end{tabular}

A summary of the distribution of the absolute bias shows that before matching: Mean = 8.16; $\mathrm{SD}=8.53$ and after matching: Mean $=3.21 ; \mathrm{SD}=2.12$ 
Table A3 shows results from balance tests of the estimation performed with Model 2 on the effect of high work ethics on use of drugs. The output shows values of each variable for the matched sample. In each row, it shows the mean of the variable for the treatment group and the mean for the control group. It also shows the "\%bias," which is the standardized bias. This "bias" is defined as the difference of the mean values of the treatment group and the (not matched / matched) non treatment group, divided by the square root of the average sample variance in the treatment group and the not matched non treatment group. A summary of the distribution of the absolute bias shows that before matching: Mean $=8.16$; $\mathrm{SD}=8.53$ and after matching: Mean $=3.21 ; \mathrm{SD}=2.12$. The table also shows the \% reduction in bias, which is how much of this bias was eliminated by matching. In this example, there are few variables exhibiting negative values for this column (meaning that the bias increased as a result of matching) and these are mostly cases in which the bias was already very low before matching. To assess balance, one should look at both the bias and the mean differences between treatment and control in the matched sample. In our example, the bias is significantly reduced after matching (the mean goes from 8.16 to 3.21). The last two columns presents results from a t-test on the hypothesis that the mean value of each variable is the same in the treatment group and the non-treatment group after matching. If $\mathrm{p}>0.1$, the null hypothesis cannot be rejected on the $10 \%$ significance level. The null hypothesis that the mean values of the two groups do not differ after matching cannot be rejected for most of the variables included in our analysis. By matching, the differences between treatment group and non-treatment group are reduced considerably. 
Table A4 Effect of other independent variables on health behaviours OLS Estimation Results from Model 2

\begin{tabular}{|c|c|c|c|c|}
\hline & $\begin{array}{c}\text { Ever tried } \\
\text { cannabis }\end{array}$ & $\begin{array}{c}\text { Ever tried other } \\
\text { drugs }\end{array}$ & $\begin{array}{c}\text { First sexual } \\
\text { intercourse }<16\end{array}$ & $\begin{array}{c}\text { Ever had } \\
\text { unprotected sex }\end{array}$ \\
\hline \multirow[t]{2}{*}{ KS2 score } & 0.011 & 0.005 & -0.003 & -0.004 \\
\hline & $(0.002)^{* * *}$ & $(0.001)^{* * *}$ & $(0.003)$ & $(0.003)$ \\
\hline \multirow{2}{*}{ Premature birth } & -0.065 & -0.017 & 0.002 & 0.001 \\
\hline & $(0.024)^{* * *}$ & $(0.017)$ & $(0.029)$ & $(0.030)$ \\
\hline \multirow[t]{2}{*}{ Birth weight in kg } & -0.004 & 0.001 & 0.015 & -0.005 \\
\hline & (0.013) & (0.009) & $(0.016)$ & $(0.017)$ \\
\hline \multirow[t]{2}{*}{ Male } & 0.090 & 0.047 & 0.030 & 0.038 \\
\hline & $(0.013)^{* * *}$ & $(0.009)^{* * *}$ & $(0.016)^{*}$ & $(0.017)^{* *}$ \\
\hline \multirow{2}{*}{$\begin{array}{l}\text { Single parent } \\
\text { household at birth }\end{array}$} & 0.075 & 0.029 & 0.066 & 0.085 \\
\hline & $(0.018)^{* * *}$ & $(0.012)^{* *}$ & $(0.021)^{* * *}$ & $(0.022)^{* * *}$ \\
\hline \multirow[t]{2}{*}{ Mother $<20$ at birth } & 0.008 & 0.043 & 0.014 & 0.058 \\
\hline & $(0.031)$ & $(0.021)^{* *}$ & $(0.036)$ & $(0.038)$ \\
\hline \multirow[t]{2}{*}{ Black } & -0.126 & -0.132 & -0.024 & -0.005 \\
\hline & $(0.032)^{* * *}$ & $(0.022)^{* * *}$ & $(0.040)$ & $(0.041)$ \\
\hline \multirow[t]{2}{*}{ Asian } & -0.212 & -0.113 & -0.212 & -0.148 \\
\hline & $(0.023)^{* * *}$ & $(0.016)^{* * *}$ & $(0.040)^{* * *}$ & $(0.042)^{* * *}$ \\
\hline \multirow[t]{2}{*}{ Mixed } & -0.032 & -0.062 & -0.028 & -0.023 \\
\hline & $(0.028)$ & $(0.020)^{* * *}$ & $(0.034)$ & $(0.036)$ \\
\hline \multirow{2}{*}{$\begin{array}{l}\text { Number of } \\
\text { older siblings }\end{array}$} & 0.027 & 0.007 & 0.013 & 0.008 \\
\hline & $(0.007)^{* * *}$ & $(0.005)$ & $(0.008)$ & (0.009) \\
\hline \multirow{2}{*}{$\begin{array}{l}\text { Grandparents went } \\
\text { to university }\end{array}$} & 0.003 & 0.003 & -0.010 & -0.038 \\
\hline & $(0.023)$ & $(0.016)$ & $(0.029)$ & $(0.031)$ \\
\hline \multirow{2}{*}{$\begin{array}{l}\text { Child has special } \\
\text { needs }\end{array}$} & -0.030 & -0.010 & 0.010 & -0.012 \\
\hline & $(0.018)$ & $(0.013)$ & $(0.022)$ & $(0.023)$ \\
\hline \multirow[t]{2}{*}{ Child has a disability } & -0.006 & -0.011 & 0.003 & -0.006 \\
\hline & $(0.020)$ & $(0.014)$ & $(0.023)$ & $(0.024)$ \\
\hline \multirow{2}{*}{$\begin{array}{l}\text { Main parent has a } \\
\text { disability }\end{array}$} & 0.032 & 0.006 & 0.040 & 0.035 \\
\hline & $(0.017)^{*}$ & $(0.012)$ & $(0.020)^{* *}$ & $(0.021)^{*}$ \\
\hline \multirow{2}{*}{$\begin{array}{l}\text { Mother has a } \\
\text { university degree }\end{array}$} & 0.111 & 0.049 & -0.020 & -0.007 \\
\hline & $(0.026)^{* * *}$ & $(0.018)^{* * *}$ & $(0.032)$ & $(0.034)$ \\
\hline \multirow{2}{*}{$\begin{array}{l}\text { Mother has other } \\
\text { higher education }\end{array}$} & 0.092 & 0.020 & -0.009 & 0.032 \\
\hline & $(0.025)^{* * *}$ & $(0.018)$ & $(0.031)$ & $(0.033)$ \\
\hline \multirow{2}{*}{$\begin{array}{l}\text { Mother senior high } \\
\text { school graduate }\end{array}$} & 0.033 & 0.033 & 0.009 & 0.008 \\
\hline & $(0.025)$ & $(0.017)^{*}$ & $(0.030)$ & $(0.032)$ \\
\hline \multirow{2}{*}{$\begin{array}{l}\text { Mother high school } \\
\text { graduate }\end{array}$} & 0.015 & 0.009 & 0.026 & 0.002 \\
\hline & $(0.022)$ & $(0.015)$ & $(0.027)$ & $(0.028)$ \\
\hline \multirow{4}{*}{$\begin{array}{l}\text { Mother junior high } \\
\text { school graduate } \\
\text { Mother has other } \\
\text { qualification }\end{array}$} & 0.004 & -0.021 & 0.048 & 0.045 \\
\hline & $(0.029)$ & $(0.020)$ & $(0.035)$ & $(0.036)$ \\
\hline & 0.026 & 0.007 & 0.003 & -0.069 \\
\hline & $(0.042)$ & $(0.029)$ & $(0.051)$ & $(0.053)$ \\
\hline R squared & 0.07 & 0.05 & 0.03 & 0.03 \\
\hline N. observations & 4,941 & 4,942 & 3,620 & 3,742 \\
\hline
\end{tabular}

Note: Standard errors in brackets. * indicates that the underlying coefficient is significant at $10 \%$ level, $* *$ at $5 \%$ and $* * *$ at $1 \%$. 
Table A4 Effect of other independent variables on health behaviours: OLS Estimation Results from Model 2 (Contd.)

\begin{tabular}{|c|c|c|c|c|}
\hline & $\begin{array}{l}\text { Heavy } \\
\text { drinking }\end{array}$ & Often drunk & Never drunk & $\begin{array}{l}\text { Low physical } \\
\text { activity }\end{array}$ \\
\hline KS2 Score & 0.014 & 0.002 & -0.003 & 0.001 \\
\hline & $(0.002)^{* * *}$ & $(0.002)$ & $(0.001)^{* *}$ & $(0.002)$ \\
\hline $\begin{array}{l}\text { Birth weight in } \\
\mathrm{kg}\end{array}$ & $\begin{array}{l}-0.022 \\
(0.023)\end{array}$ & $\begin{array}{l}0.011 \\
(0.025)\end{array}$ & $\begin{array}{l}0.007 \\
(0.016)\end{array}$ & $\begin{array}{l}-0.029 \\
(0.017)^{*}\end{array}$ \\
\hline Premature birth & $\begin{array}{l}0.001 \\
(0.012)\end{array}$ & $\begin{array}{l}0.047 \\
(0.014)^{* * *}\end{array}$ & $\begin{array}{l}0.007 \\
(0.009)\end{array}$ & $\begin{array}{l}-0.001 \\
(0.009)\end{array}$ \\
\hline Male & $\begin{array}{l}0.092 \\
(0.013) * * *\end{array}$ & $\begin{array}{l}-0.009 \\
(0.014)\end{array}$ & $\begin{array}{l}-0.017 \\
(0.009)^{*}\end{array}$ & $\begin{array}{l}-0.113 \\
(0.010)^{* * *}\end{array}$ \\
\hline $\begin{array}{l}\text { Single parent } \\
\text { household at birth }\end{array}$ & $\begin{array}{l}-0.024 \\
(0.017)\end{array}$ & $\begin{array}{l}0.048 \\
(0.019)^{* * *}\end{array}$ & $\begin{array}{l}-0.016 \\
(0.012)\end{array}$ & $\begin{array}{l}0.014 \\
(0.013)\end{array}$ \\
\hline Mother $<20$ at birth & $\begin{array}{l}-0.032 \\
(0.030)\end{array}$ & $\begin{array}{l}-0.006 \\
(0.034)\end{array}$ & $\begin{array}{l}0.029 \\
(0.021)\end{array}$ & $\begin{array}{l}0.023 \\
(0.022)\end{array}$ \\
\hline Black & $\begin{array}{l}-0.163 \\
(0.032)^{* * *}\end{array}$ & $\begin{array}{l}-0.157 \\
(0.036)^{* * *}\end{array}$ & $\begin{array}{l}0.183 \\
(0.023)^{* * *}\end{array}$ & $\begin{array}{l}0.049 \\
(0.023)^{* *}\end{array}$ \\
\hline Asian & $\begin{array}{l}-0.040 \\
(0.028)\end{array}$ & $\begin{array}{l}-0.105 \\
(0.032) * * *\end{array}$ & $\begin{array}{l}0.079 \\
(0.020)^{* * *}\end{array}$ & $\begin{array}{l}-0.006 \\
(0.017)\end{array}$ \\
\hline Mixed & $\begin{array}{l}-0.054 \\
(0.027)^{* *}\end{array}$ & $\begin{array}{l}-0.023 \\
(0.030)\end{array}$ & $\begin{array}{l}0.051 \\
(0.019)^{* * *}\end{array}$ & $\begin{array}{l}0.025 \\
(0.020)\end{array}$ \\
\hline N. older siblings & $\begin{array}{l}-0.008 \\
(0.006)\end{array}$ & $\begin{array}{l}0.018 \\
(0.007)^{* *}\end{array}$ & $\begin{array}{l}-0.004 \\
(0.005)\end{array}$ & $\begin{array}{l}0.004 \\
(0.005)\end{array}$ \\
\hline $\begin{array}{l}\text { Grandparents went } \\
\text { to university }\end{array}$ & $\begin{array}{l}0.029 \\
(0.022)\end{array}$ & $\begin{array}{l}-0.046 \\
(0.025)^{*}\end{array}$ & $\begin{array}{l}0.008 \\
(0.016)\end{array}$ & $\begin{array}{l}0.008 \\
(0.017)\end{array}$ \\
\hline $\begin{array}{l}\text { Child has special } \\
\text { needs }\end{array}$ & $\begin{array}{l}-0.014 \\
(0.017)\end{array}$ & $\begin{array}{l}-0.050 \\
(0.019)^{* *}\end{array}$ & $\begin{array}{l}0.043 \\
(0.012)^{* * *}\end{array}$ & $\begin{array}{l}0.005 \\
(0.013)\end{array}$ \\
\hline $\begin{array}{l}\text { Child has a } \\
\text { disability }\end{array}$ & $\begin{array}{l}-0.041 \\
(0.018)^{* *}\end{array}$ & $\begin{array}{l}-0.016 \\
(0.020)\end{array}$ & $\begin{array}{l}0.024 \\
(0.013)^{*}\end{array}$ & $\begin{array}{l}0.006 \\
(0.014)\end{array}$ \\
\hline $\begin{array}{l}\text { Main parent has a } \\
\text { disability }\end{array}$ & $\begin{array}{l}0.008 \\
(0.016)\end{array}$ & $\begin{array}{l}0.000 \\
(0.018)\end{array}$ & $\begin{array}{l}0.018 \\
(0.011)^{*}\end{array}$ & $\begin{array}{l}0.010 \\
(0.012)\end{array}$ \\
\hline $\begin{array}{l}\text { Mother has a } \\
\text { university degree }\end{array}$ & $\begin{array}{l}0.138 \\
(0.025)^{* * *}\end{array}$ & $\begin{array}{l}0.045 \\
(0.028)\end{array}$ & $\begin{array}{l}-0.042 \\
(0.018)^{* *}\end{array}$ & $\begin{array}{l}-0.052 \\
(0.019)^{* * *}\end{array}$ \\
\hline $\begin{array}{l}\text { Mother has other } \\
\text { higher education }\end{array}$ & $\begin{array}{l}0.103 \\
(0.025) * * *\end{array}$ & $\begin{array}{l}0.024 \\
(0.028)\end{array}$ & $\begin{array}{l}-0.037 \\
(0.017)^{* *}\end{array}$ & $\begin{array}{l}-0.030 \\
(0.018)^{*}\end{array}$ \\
\hline $\begin{array}{l}\text { Mother senior high } \\
\text { school graduate }\end{array}$ & $\begin{array}{l}0.048 \\
(0.024)^{* *}\end{array}$ & $\begin{array}{l}0.029 \\
(0.027)\end{array}$ & $\begin{array}{l}-0.019 \\
(0.017)\end{array}$ & $\begin{array}{l}-0.030 \\
(0.018)^{*}\end{array}$ \\
\hline $\begin{array}{l}\text { Mother high school } \\
\text { graduate }\end{array}$ & $\begin{array}{l}0.058 \\
(0.021)^{* * *}\end{array}$ & $\begin{array}{l}0.010 \\
(0.024)\end{array}$ & $\begin{array}{l}-0.020 \\
(0.015)\end{array}$ & $\begin{array}{l}-0.012 \\
(0.016)\end{array}$ \\
\hline $\begin{array}{l}\text { Mother junior high } \\
\text { school graduate }\end{array}$ & $\begin{array}{l}0.018 \\
(0.028)\end{array}$ & $\begin{array}{l}0.036 \\
(0.031)\end{array}$ & $\begin{array}{l}-0.005 \\
(0.019)\end{array}$ & $\begin{array}{l}-0.014 \\
(0.021)\end{array}$ \\
\hline \multirow[t]{2}{*}{$\begin{array}{l}\text { Mother has other } \\
\text { qualification }\end{array}$} & $\begin{array}{l}0.027 \\
(0.041)\end{array}$ & $\begin{array}{l}0.079 \\
(0.047)^{*}\end{array}$ & $\begin{array}{l}-0.032 \\
(0.029)\end{array}$ & $\begin{array}{l}0.014 \\
(0.030)\end{array}$ \\
\hline & -0.243 & 0.042 & 0.156 & 0.176 \\
\hline R squared & 0.06 & 0.02 & 0.03 & 0.04 \\
\hline N. observations & 4,547 & 4,443 & 4,443 & 4,988 \\
\hline
\end{tabular}

Note: Standard errors in brackets. * indicates that the coefficient is significant at $10 \%$ level, **at $5 \%$ and ***at $1 \%$. 
Table A5 Effect of personality traits on health behaviours - Propensity Score Matching Results - Sensitivity analysis with additional variables (maternal employment and family income at wave 1)

\begin{tabular}{|c|c|c|c|c|c|c|c|c|}
\hline Model 2 & $\begin{array}{l}\text { Ever tried } \\
\text { cannabis }\end{array}$ & $\begin{array}{l}\text { Ever tried } \\
\text { other drugs }\end{array}$ & $\begin{array}{l}\text { Had first } \\
\text { sexual } \\
\text { intercourse } \\
<16\end{array}$ & $\begin{array}{l}\text { Ever had } \\
\text { unprotected sex }\end{array}$ & $\begin{array}{l}\text { Heavy } \\
\text { drinking }\end{array}$ & $\begin{array}{l}\text { Often } \\
\text { Drunk }\end{array}$ & Never Drunk & $\begin{array}{l}\text { Low } \\
\text { Physical } \\
\text { Activity }\end{array}$ \\
\hline $\begin{array}{l}\text { External Locus of } \\
\text { Control }\end{array}$ & $\begin{array}{l}0.025 \\
(0.027)\end{array}$ & $\begin{array}{l}0.024 \\
(0.018)\end{array}$ & $\begin{array}{l}0.010 \\
(0.031)\end{array}$ & $\begin{array}{l}0.064 \\
(0.031)^{* *}\end{array}$ & $\begin{array}{l}0.021 \\
(0.023)\end{array}$ & $\begin{array}{l}0.033 \\
(0.027)\end{array}$ & $\begin{array}{l}-0.006 \\
(0.017)\end{array}$ & $\begin{array}{l}0.004 \\
(0.019)\end{array}$ \\
\hline $\begin{array}{l}\text { High Work } \\
\text { Ethics }\end{array}$ & $\begin{array}{l}-0.058 \\
(0.024)^{* * *}\end{array}$ & $\begin{array}{l}-0.024 \\
(0.013) *\end{array}$ & $\begin{array}{l}-0.083 \\
(0.029)^{* *}\end{array}$ & $\begin{array}{l}-0.071 \\
(0.030)^{* * *}\end{array}$ & $\begin{array}{l}-0.007 \\
(0.022)\end{array}$ & $\begin{array}{l}-0.007 \\
(0.025)\end{array}$ & $\begin{array}{l}-0.001 \\
(0.017)\end{array}$ & $\begin{array}{l}-0.030 \\
(0.018)^{*}\end{array}$ \\
\hline $\begin{array}{l}\text { Low } \\
\text { Self- Esteem }\end{array}$ & $\begin{array}{l}0.144 \\
(0.023) * * *\end{array}$ & $\begin{array}{l}0.050 \\
(0.016)^{* * *}\end{array}$ & $\begin{array}{l}0.053 \\
(0.027)^{* *}\end{array}$ & $\begin{array}{l}0.069 \\
(0.028) * * *\end{array}$ & $\begin{array}{l}0.008 \\
(0.021)\end{array}$ & $\begin{array}{l}0.034 \\
(0.024)\end{array}$ & $\begin{array}{l}0.002 \\
(0.014)\end{array}$ & $\begin{array}{l}0.037 \\
(0.018)^{* *}\end{array}$ \\
\hline N. observations & 4,037 & 4,039 & 2,998 & 3,102 & 3,761 & 3,672 & 3,672 & 4,071 \\
\hline
\end{tabular}

Note: Standard errors are in brackets. * indicates that the underlying coefficient is significant at $10 \%$ level, ** at $5 \%$ and $* * *$ at $1 \%$. Additional variables included in the analysis are listed at p. 9 
